\title{
Reconsidering Land System Changes in Borderlands: Insights from the China-ASEAN Borderland
}

\section{Nowe podejście do systemowych zmian na lądzie na pograniczu: przypadek pogranicza Chin i innych krajów azjatyckich}

\author{
Xiaobo Hua, Yasuyuki Kono \\ Center for Southeast Asian Studies, Kyoto University, 46 Shimoadachi-cho, \\ Yoshida Sakyo-ku, Kyoto, 606-8501, Japan \\ E-mail (corresponding author): huaxiaobo1988@gmail.com
}

\begin{abstract}
This study contributes to the literature on how to explicitly describe, track, and interpret the structure and dynamics of land systems in borderlands. The shift in land system science analytics from place-based toward larger-scale analysis of interactions and connections in a globalized context provides an opportunity to synthesize the knowledge about borderlands. This paper argues that studies on land system changes in borderlands need to thoroughly link the features of borderland regions with multiple interactions - on either or both sides of a border rather than simply focusing on shifts within closed national boundaries. Furthermore, this paper provides important insights that can advance existing approaches to track and interpret changes in the land systems of borderlands.
\end{abstract}

Key words: borderland, land system, land use change, interactions, synthesis, sustainability

\section{Streszczenie}

Niniejsze opracowanie przyczynia się do jednoznacznego opisu, śledzenia i interpretacji struktury i dynamiki systemów lądowych na obszarach przygranicznych. Przejście w analizie nauk o systemie lądowym z analizy opartej na miejscu na analizę interakcji i połączeń na większą skalę w zglobalizowanym kontekście daje możliwość nowej syntezy wiedzy na temat pogranicza. W niniejszym artykule wykazuje się, że badania zmian w systemie lądowym na obszarach przygranicznych muszą dokładnie wiązać cechy regionów przygranicznych z wieloma interakcjami - po jednej lub po obu stronach granicy - zamiast koncentrować się wyłącznie na przesunięciach w obrębie zamkniętych granic krajowych. Ponadto niniejszy artykuł zawiera ważne informacje, które mogą usprawnić istniejące podejścia do śledzenia i interpretacji zmian w systemach lądowych pogranicza.

Słowa kluczowe: pogranicze, system lądowy, zmiana użytkowania gruntów, interakcje, synteza, zrównoważoność

\section{Introduction}

Geopolitically, borders are lines drawn on maps, that materialize as fences, hedgerows, signs, or checkpoints that divide the world into specific territories and categories. Furthermore, these borders symbolize geographic frontiers of nation-states, as well as power (Donnan and Wilson, 2001; Gainsborough, 2008; Gallaher et al., 2009; Diener and Hagen, 2012). Borderlands are defined as geographic regions surrounding these international borders where geographic, political, demographic, cultural, and economic circumstances or processes may interact (Parker, 2006; Gregory et al., 2011).

Over recent decades, transitional political boundaries have challenged the centre-periphery model or the state-centred epistemology, both of which have regarded borderlands as the margins of state territories for a long time (van Schendel, 2005). Additionally, economic globalization processes, such as the Greater Mekong Subregion (GMS) project, promoted by the Asian Development Bank (ADB), and 
global land grabs, have deeply impacted cross-border flows (e.g. the flow of capital and labour migration) (Newman, 2006; Arnold and Pickles, 2011; Baird et al., 2019). Therefore, it is necessary to find a suitable approach that enables a better understanding of borderlands that are subject to multiple interactions.

Land systems constitute terrestrial components of the Earth system, land use activities, and processes by human being (Verburg et al., 2013). Land system studies often suffer from a lack of knowledge generalization of land system changes in borderlands. Although empirical and case studies have addressed this issue (Liu et al., 2006; Trincsi and Turner, 2014; Pham et al., 2015), they tend to discuss the matter within an enclosed space, and focus less on multiple interactions occurring in borderlands. Several reasons can be identified that lead to the resulting knowledge gaps. First, previous studies mainly focused on the changing process and patterns in a particular place and under a fixed institutional setting and political boundary (Liu et al., 2013). Under these specific circumstances, borderlands are typically regarded as remote, marginal, and less developed areas of a nation-state. Second, flows and mobility are not easy to track within borderlands, especially with regard to informal or illegal interactions. Third, knowledge of border issues has largely been separated into different disciplines (Kolossov and Scott, 2013). For instance, anthropologists may be particularly interested in topics such as cross-border marriage, economists focus on cross-border trade, and political scientists specifically focus on strategic bilateral relationships. Beyond the changes in borderlands' land systems, many factors are intermingled in a complex way. It is therefore necessary to generalize and synthesize the knowledge comprehensively.

This paper contributes to the current literature on how to explicitly describe, track, and interpret the structure and dynamics of land systems in borderlands with a specific focus on the China-ASEAN borderland (ASEAN stands for the Association of South East Asian Nations and this borderland is primarily referred to as including China, Myanmar, Laos, and Vietnam terrestrially). In this paper, we focus upon land system dynamics in the borderland in the context of regional integration and transnational linkages. Furthermore, this paper summarizes two types of land system changes (namely the expansion of industrial crops and forest plantations and replacing rice-farming by crop diversification and intensification) in the China-ASEAN borderland and discusses impacts on these land system changes from different perspectives. Then, an applicable framework with four types of interactions beyond these mentioned impacts is explored. This paper concludes by discussing challenges and future directions for land system studies in borderlands.

\section{Recent land system changes in the China-ASEAN borderland}

For the past two decades, the China-ASEAN borderland has entered a transition phase from the geographical periphery and margins of the nation-states to a frontier characterized by regional markets and comparative advantages in land, labour, and capital responses to economic globalization (Fox, 2009; Baird and Li, 2017; Friis and Nielsen, 2017a). A number of economic cooperation programs and projects contribute to this process, such as the GMS (1992), the China-ASEAN Free Trade Area (2010), the Belt and Road Initiative (2013), and the Lancang Mekong Cooperation Mechanism (2016). In this context, the China-ASEAN borderland has become a region that offers opportunities for investment, employment, regional integration, and transnational linkages with regard to rapid mobility and migration. This transition has led to land use changes and livelihood transitions from subsistence farming to commercialized farming in local societies (Friis and Nielsen, 2016; Kono et al., 2018; Hua et al., 2019). In general, two types of land system changes can be identified in this borderland. The first is the expansion of the cultivation of industrial crops and forest plantations, which replace swidden farming in the upland (Lu, 2017; Borras et al., 2018; Rousseau, 2018; Woods, 2019). Prominent examples are rubber, Jatropha, and eucalyptus plantations. The second is crop diversification and intensification in the lowland, where intensive rice cultivation was previously emphasized for agricultural production (Devendra and Thomas, 2002; Zhang et al., 2014; Friis and Nielsen, 2017a; Kubo, 2018), which has been changed to cash crops, such as banana and watermelon. In fact, many issues are mixed on each or both sides, such as China's sloping land conversion program, the poverty alleviation campaign, the opium replacement program, and the agriculture going out strategy, all of which contribute to these changes.

\section{Reconsidering the impacts on land system changes in the China-ASEAN borderland}

\section{Multi-ethnic habitats}

Ethnic minorities (Hall, 2013), who are often regarded as economically poor compared to the dominant majority (Sturgeon, 2010, 2013; Turner, 2013), often inhabit borderlands. Three important points need to be considered. First, ethnic minorities on both sides of a border most likely belong to the same ethnic group with shared ethno-linguistic and religious plurality, such as the Hani in China and the Akha in Laos (Sturgeon, 2007). Second, although each ethnic group has its own cultural characteristics, ethnic groups also share some common traits in relation to land use dynamics. 
A few examples substantiate this point. In the ChinaMyanmar borderland, upland-lowland interactions among different ethnic groups have been examined. For example, in the past, due to inconvenient transport and poor access to the market, the ethnic Palaung people in the mountainous region of northern Myanmar and Southwestern China sold their cultivated tea to the ethnic Shan people in the lowlands. The income from selling tea was used to purchase rice and to manufacture goods (Kojima and Badenoch, 2013). Third, ethnic people are currently closely linked to a globalized market, and traditional practices are changing toward being modern by a series of state-led modernization programs. For example, the traditional use of water buffalos has dramatically decreasing and even disappeared in the upland Akha ethnic society due to rubber expansion and intensive agriculture specifically advertised by state policies and projects (Rousseau and Sturgeon, 2019). Therefore, when examining land system changes in multi-ethnic borderlands, it is essential to fully understand the culturally indigenous knowledge and local development patterns, since some of these influence decision-making on land use (Lambin and Geist, 2008).

\section{De-territorialization/Re-territorialization}

According to van Schendel (2005), the geography of territorial states is de-territorialized in the context of a borderless and globalized world, and transnational flows of capital, people, goods, and information are undermining the concept of territoriality. Furthermore, a re-territorialization process is emerging, as well as the re-scaling of territoriality in a global restructuring, such as sub-national export zones. GMS is a typical example. As Turner (2013) argued, the creation of GMS and corridors provides an opportunity for governments to extend their territorialization and create new state spaces. Diener and Hagen (2012) noted that new economics, as well as social and political realities, lead to the emergence of new forms of bordering and alternative spatial realities. These processes deeply influence land use patterns that reflect state plans, such as an opening-up strategy. Epistemologically and methodologically, this requires that land system science overcomes national boundaries, and calls for the study of borderlands.

\section{Cross-border/Transnational labour migration}

Cross-border migration is not only a reality of the daily lives of borderland residents, but it is also an important way to make a living by turning residents into a labour force. In cross-border migration, traditional and newly induced labour migration coexist. For example, In the China-Vietnam borderland, many Vietnamese citizens go to the city of Dongxing in Guangxi Province, China for off-farm opportunities (for example, as workers in logistics companies or salespeople in stores); this eases their economic plight due to a labour shortage, and contributes to the growth of the urban economy ${ }^{1}$.

Despite off-farm employment, cross-border labour migration also occurs in the agricultural sector. For example, in the China-Myanmar borderland, Burmese labour migration into China contributes to agricultural intensification in the context of aging and out-migration of the local labour force on the Chinese side of the border (Hua et al., 2019). These Burmese labour migrants form a mix of seasonal and long-term migrants (Baird and Li, 2017; Hua et al., 2019). Therefore, it is necessary to reconsider the hypothesis related to upland land system changes by integrating the context of out-migration when supplementing labour forces are available.

Rich natural resources and cross-border/transnational investment

Borderlands likely host cross-border or transnational corporations that are engaged in resource extraction (Hall, 2013). This results in land system changes, such as deforestation and negative impacts on forestdependent livelihoods. Farmland resources are commonly targeted by transnational investment. For example, in the China-Laos borderland, Chinese investors (including small companies, businessmen, and joint ventures) invested in commercial banana plantations in northern Laos for export to China, due to the quickly increasing demand for fresh fruit in China (Friis and Nielsen, 2017a). In Myanmar, borders with rich forest resources and timber reserves are closely connected to China's domestic market, which also attract a high level of illegal logging (Prescott et al., 2017).

\section{Formal/official cross-border trade}

People engage in cross-border trade, work, and movement, when they share close ties with neighbouring states (Hall, 2013; Kubo, 2016). Different forms of trading are used in borderlands. With regard to legality and rationality, these have been classified into two groups in this paper: (1) formal or official, and (2) informal and illegal or illicit. Formal or official trade is globally pervasive and supports the flow of goods and services over cross-national borders by utilizing the advantages of location and other privileges, such as duty-free merchandising. A typical example can be found in the China-Myanmar borderland, where from 1991-1992 and 2007-2008, the value of trade along the border accounted for an average of $61.47 \%$ of Myanmar's total border commerce and increased from 139.27 to $1,329.53$ million US dollars (Steinberg and Fan, 2012). The most fre-

\footnotetext{
${ }^{1}$ It is available at: http://news.sina.com.cn/o/2018-01-18/ doc-ifyquixe3542301.shtml.
} 
quently exported items from Myanmar to China are agricultural, aquatic, and rubber products, while the main items Myanmar imports from China are electronic goods, machinery, textiles, and chemicals (Steinberg and Fan, 2012). The increasing demand for agricultural products, such as tropical fruit, by China will deeply influence Myanmar land system changes and develop these from traditional subsistence farming to intensive and modern technologydriven commercialized farming.

\section{Informal and illegal or illicit cross-border trade} Despite formal trade in the borderlands, informal (e.g., informal gemstone mining) and illegal or illicit (e.g., illegal logging and timber trade, illicit drugs, and smuggling of buffalo) trade is widespread (EIA/Telepak, 2008; Diener and Hagen, 2012; Turner, 2013; Lahiri-Dutt and Brown, 2017). In practice, it is difficult to distinguish them clearly due to the complex cultural and political-economic features that influence cross-border trade. For example, the ethnic groups of the China-Laos and China-Vietnam borderlands devised a series of border strategies and maintained their own and trans-border trade networks for centuries; however, much of the trade was made illicit by government policies (Diana, 2013; Turner, 2013). In general, there are three types of informal cross-border trade (Lesser and MoiséLeeman, 2009):

(1) Unregistered traders or firms operating entirely outside the formal economy.

(2) Registered firms that fully evade regulations and duties regarding trade.

(3) Registered firms that partially evade regulations and duties regarding trade by resorting to illegal practices.

Certain trading processes are difficult to track (such as illegal migration and smuggling). Even so, it is useful to adopt indirect approaches. For example, Kubo (2016) noticed discrepancies in border trade statistics between those compiled by the Myanmar Customs Department and the General Administration of Customs of China. For example, a number of agricultural products in Myanmar's exports statistics, such as sugar, maize, beans, sesame seeds, and melon, are not recorded in China's imports statistics, which thus implies that agricultural products are smuggled from Myanmar to China (Kubo, 2016).

Notably, widely existing informal and illegal/illicit commerce in borderlands may significantly influence land use, livelihoods, food security, and other social issues, which are closely connected to border governance and sustainability. Previous studies on land system changes have seldom considered the above-mentioned factors, which remain part of a big research gap in terms of comprehensively understanding the mechanism of land system changes in borderlands.

\section{Insights from the China-ASEAN borderland}

The understanding of borderlands needs to overcome the separation between political, social, and economic spaces and integrate a bordering process (Newman, 2006). Borderlands involve attempts to describe the lives and imaginative geographies of people whose daily practices, economic activities, and cultural connections cross the borders that define nation-states (Gregory et al., 2011). Therefore, in the context of neoliberal capital flows and cyber community linkages across space (Diener and Hagen, 2012), an enormous challenge remains with regard to fostering a deeper understanding of land system changes in borderlands. Newman (2006) argued that creating a single theory is not possible - nor is it necessary - for understanding borders. However, we argue that theoretical ideas from different disciplines could help to synthesize the evidence in order to comprehensively grasp borderland processes.

Theoretically, many investigations have contributed to the understanding of land system dynamics in borderlands. For example, Minghi (1991) developed a borderland transaction flow model for exploring border landscapes. Sturgeon (2007) came up with the notion of landscape plasticity, which vividly delineates border interactions. She described it as the ability to adjust complex land uses over time in response to local needs, state plans, and border possibilities. For example, the varying political approaches in China and Thailand towards the marginalized ethnic people led to divergent outcomes of the border landscape in Akha societies, whereas the landscapes in these two places were similar in the 1950s. This example clearly shows how various factors, such as distinct state policies, can influence change in a border landscape. For example, border development is connected to national plans through which most flows (such as labour migrants and refugees, or the trade of various goods) are unauthorized by states concerned, indicating continual struggles between the powers of territorial control and those of crossborder networking (van Schendel, 2005). Similarly, in migration studies, the push and pull model is often used for discourses on labour migration from one place to another, which could partly explain crossborder migration and provide a reference for re-considering factors of the sending and receiving place/country.

Recently, a conceptual framework, telecoupling, was provided to reflect the interactions between distant places, encompassing five parts of coupled human and natural systems, flows, agents, causes, and effects (Liu et al., 2013). The international soybean trade between China and Brazil is a typical issue that using a telecoupling framework entails. Due to China's increasing demand for soybeans, the Chinese government decided to expand its import of 
soybeans from Brazil, which caused dramatic changes in land systems and other socioeconomic and environmental effects there. Afterward, some studies deeply considered the potentiality of linking this framework to re-think land system changes (Eakin et al., 2014; Liu et al., 2014; Friis and Nielsen, 2016).

Several case studies have made contributions to recent land use changes by applying this framework, especially in Asian borderlands (Baird and Fox, 2015; Leisz et al., 2016; Friis and Nielsen, 2017b; Zimmerer et al., 2018). When conducting case studies using the telecoupling framework, some researchers argue that reality is complicated. They made some amendments to the framework and came up with new notions based on this framework in an innovative way (such as nearby telecoupling, transnational labour and opportunistic telecoupling) (Baird and Fox, 2015). In addition, some researchers found that challenges remain in the literature on telecoupling land use changes, such as how to draw clear system boundaries and shed light on accurate scales (Friis and Nielsen, 2017b). Since then, the telecoupling framework has been updated to be more comprehensive in order to effectively solve the problems of human-nature interactions (intracoupling) as well as nearby pericoupling and faraway telecoupling. The method was named the metacoupling framework (Liu, 2017). Compared to the former version, metacoupling is more inclusive, especially in terms of answering questions such as where and how far away a system is. In practice, Liu (2017) described framework operationalization. This metacoupling framework has already been used to rethink how to achieve the United Nations (UN) Sustainable Development Goals (SDGs), such as eradicating poverty (Liu, 2018).

Here, inspired by the above existing literature and theoretical thinking on human-natural systems and geopolitical works, we propose a framework that describes multiple interactions, and to re-clarify the interactions and consequences of land system changes in the borderlands of two countries. This two-state model is simplified, and is also a prototype that describes borderlands encompassing more than two countries. Geographically and abstractly, territorial borders divide two adjacent states; within a certain range, we can define borderlands. With the change in scales, a borderland may be a county, a city, or even a larger administrative unit or connected units, which are similar to buffer zones in geoscience. These two sides are closely interlocked, interactional, and interdependent. We define the processes (e.g., migration) as influencing and responding, which could be regarded as driving and feedback.

In borderlands, we suggest that four hypothetical interactions generally help to (re)shape land systems. These four interactions are depicted in Figure 1 and inspired by Minghi (1991), Sturgeon (2007), Liu et al. (2013), and Liu (2017). Four interactions have different historical background and current functions. The first interaction process consists of local interactions (A in Figure 1), which is similar to intracoupling (Liu, 2017). This includes a series of factors that contribute to land system changes on each side of a boundary, such as interethnic and upland-lowland economic linkages.

Borderlands are geographically far removed and at a state's margins. In this context, the second interaction process comprises in-country interactions (B in Figure 1), which arise from distant (but not adjacent) actors, agents, or systems. For example, local land systems may be transformed in borderlands due to governmental opening-up or land use policies. Moreover, these systems may be targets for agribusiness investment by domestic investors. Policy implementations and other socio-economic externalities can also be regarded as in-country interactions.

In addition, the adjacent two sides of a border feature mobility and migration, which exert both direct and indirect impacts on land systems. For example, as a result of Burmese labour migration into China as a substitution for out-migration and aging of the local labour force, upland land use has intensified on the Chinese side of the border and local smallholders have become entrepreneurs (direct impact). This also attract outside agribusiness investors for commercial farming (indirect impact) (Hua et al., 2019). Therefore, the third type of interaction processes contains cross-border interactions ( $\mathrm{C}$ in Figure 1), which demonstrate historical, cultural, and socio-economic interrelations. As mentioned above, borderlands are widely characterized by the flows of people, goods, and capital, such as cross-border trade or migration. Finally, it can be defined as transnational interaction (D in Figure 1), where transnational is defined as an interaction between state A (but not originating in borderland $\mathrm{A}$ ) and borderland $\mathrm{B}$, or even adjacent areas in state B. For instance, many agribusiness investors from China's inland provinces moved to Mandalay, Myanmar, to rent farmland to grow watermelons. These were then sold back to China via Myanmar's Muse (105 Miles) Trading Zone (Kubo, 2018). Mandalay is not territorially adjacent to China, but it is involved in transnational farmland investment. In addition, the international expressway between Kunming, China and Bangkok, Thailand was opened in 2008 via Laos. Governments of pertinent countries should approve the international expressway between Kunming, China and Bangkok, Thailand, considering future economic and environmental scenarios, which can improve economic connectivity. Regarding the borderlands involved in road construction, land systems in the Thailand-Laos borderland are affected by way of China. 


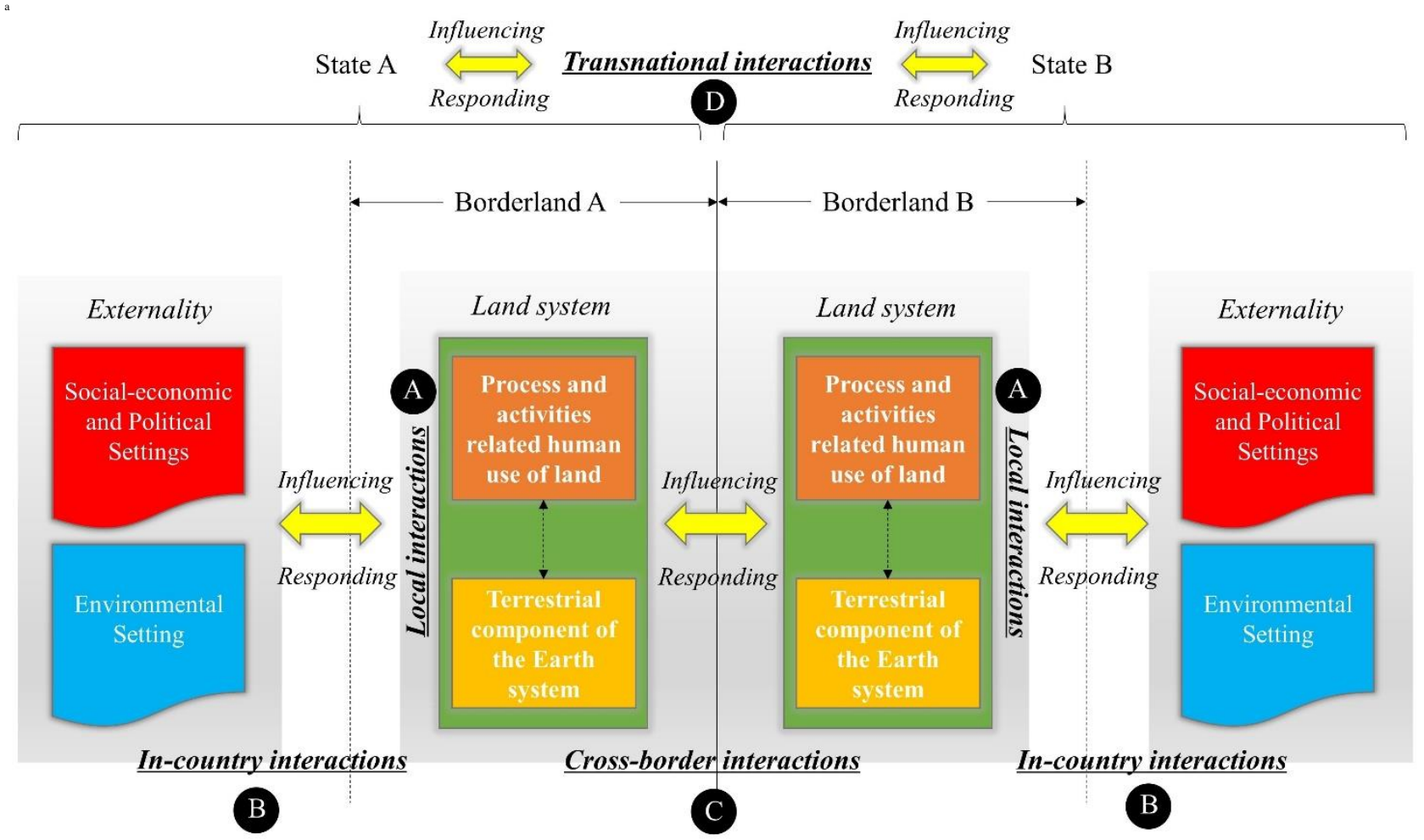

Figure 1. A conceptualized framework of border interactions in the simplified two-state model

\section{Concluding discussion: Challenges and future di- rections}

In this paper, we focus on the question of how to explicitly describe, track and interpret the structure and dynamics of land systems in borderlands; this information is scant and ambiguous in land system science. Two important points received little attention in previous studies. One is that researchers often examine what happens in borderlands within state borders, while neglecting interactions between borders. The other is that most studies focus on formal issues, such as border trade and cross-border migration. However, many informal, illegal, or illicit issues as well as uncertain conditions (such as conflicts), which are widespread in borderlands, affect interactions.

Next, we provide an applicable framework in order to better understand the research question, which is inspired by previous studies on human-environmental interactions. In this framework, we highlight that the multiple and multi-directional interactions happening in borderlands (including local, cross-border, in-country, and transnational interactions). These interactions in the borderland are part of the contemporary globalization and economic flows. In addition, several challenges and future directions require further discussion.

\section{Re-considering existing theoretical ideas}

Current theoretical ideas on land system changes have been effectively and extensively synthesized and generalized (Meyfroidt et al., 2018). However, when re-considering how these theories apply to borderlands, the phenomena need to be carefully synthesized or compared with prevailing circumstances in other countries. According to Meyfroidt et al. (2018), increasing connectivity between distant places and globalization are central drivers of land system changes, which require further exploration and theory development. In fact, not only distant but also adjacent places are becoming much more closely connected. Therefore, in borderlands, it is important to combine complex and multiple interactions to be able to explain the mechanism of land system changes. One typical example is land abandonment, a frequent phenomenon due to labour shortages in the context of China's transition economy, especially in the country's mountainous areas (Yan et al., 2016). Despite commonly argued socio-economic triggers, several underlying or embedded factors, such as human-wildlife conflict (Hua et al., 2016), have been examined, thus contributing to land abandonment studies. Generally and definitely, labour shortages under the influence of push-pull effects constitute the main explanation for rural land abandonment. However, in borderlands, this mechanism needs to be re-considered. With these effects in mind, borderlands may provide relatively large areas of land for farming and construction, with cheaper prices for investment. Furthermore, a supply and substitution of labour forces are available. Crossborder labour migration - whether temporary or long-term - is a common occurrence (Baird and Fox, 2015; Baird and Li, 2017; Hua et al., 2019), although at the local level or on the receiving side of a border, 
the workforce may be aging or engage in out-migration.

Balancing conditions on both sides of a border Another way to enhance theoretical considerations of borderlands is to scrutinize (and balance) knowledge on both sides of a border (such as through a classification system of land use types, labour migration policies, or international trade policy), especially for comparative studies. In a borderland, one side of a border could be defined as the focal system (Liu, 2017). However, if a borderland is regarded as a whole and also as the focal system itself, much more complex information should be examined. For example, when contemplating cross-labour migration in the receiving country, the dynamics of the sending area should be integrated, such as land arrangement. Institutionally, for instance, in China, rubber plantations are regarded as orchard and perennial plantations in an official classification system of land use types by the Chinese government ${ }^{2}$. However, some studies treated the rubber plantations in China as forest land (Dong et al., 2012). In contrast, in Myanmar, rubber is considered an industrial agricultural crop (Woods, 2012). In addition, shifting cultivation (also known as slash and burn or swidden agriculture) is almost no longer practiced in China, but still ongoing in Myanmar. This type of agriculture is called taungya in Burmese. Another paper noted that shwe pyaung taungya refers to rotational fallow farming fields or shifting cultivation, while taungya land refers to permanent upland fields (Woods, 2012; Andersen, 2017).

\section{Designing land systems for the sustainable develop- ment of borderlands}

As discussed, borderlands have attracted different investment types, with increasing degrees of opening up. A prominent example is agribusiness investment due to its comparative advantages in land and labour. However, direct or indirect environmental effects (e.g. heavy use and residue of chemicals for commercial banana farming and related healthcare issues in northern Laos bordering China ${ }^{3}$ need to be carefully considered to advance and develop sustainable border landscapes. Therefore, when designing land systems via policy implementation, governments should take these points into account, not only within their own borders, but also on the neighbouring side of the border.

A further point addressed the illegal and illicit aspects of land systems in borderlands. According to the SDGs, many issues and targets form new challenges for borderland systems. For example, SDG 3 ensures healthy lives and promotes wellbeing at all ages, while SDG 16 proposes to fight poverty and advocates a peaceful society. In reality, however,

\footnotetext{
${ }^{2}$ See two documents entitled $G B / T$ 19231-2003 on land terminology and $G B / T 21010-2017$ on the official classification of land use types at: http://www.gb688.cn/bzgk/gb/.
}

several issues, such as drug production and trafficking, illegal resource exploitation, and the spread of disease, negatively influence both local livelihoods and natural systems. To overcome these issues, effective border governance and cross-border collaboration are required. These issues require further investigation and should therefore be examined in future research.

\section{Acknowledgments}

The authors acknowledge the financial supports of Grants-in-Aid for Scientific Research from the Japan Society for the Promotion of Science (JSPS) (No. 19K23128), National Natural Science Foundation of China (No. 41829101) and Explorer Program from the Center for On-site Education and Research (COSER), Kyoto University. We are also grateful to Dr. Junquera Victoria for her valuable comments on an earlier draft of this paper.

\section{References}

1. ANDERSEN K. E., 2017, Codification of customary communal tenure of upland shifting cultivation communities in Myanmar, in: Shifting cultivation policies: Balancing environmental and social sustainability, ed. Cairns M., Cabi, Boston, p. 917941.

2. ARNOLD D., PICKLES J., 2011, Global work, surplus labour, and the precarious economies of the border, in: Antipode, 43(5), p. 1598-1624.

3. BAIRD I. G., FOX J., 2015, How land concessions affect places elsewhere: Telecoupling, political ecology, and large-scale plantations in Southern Laos and Northeastern Cambodia, in: Land, 4(2), p. 436-453.

4. BAIRD I. G., LI, C. 2017, Variegated borderlands governance in Dehong Dai-Jingpo Autonomous Prefecture along the China-Myanmar border, in: Geoforum, 85, p. 214-224.

5. BAIRD I. G., NOSEWORTHY W., TUYEN N. P., HA L. T., FOX J., 2019, Land grabs and labour: Vietnamese workers on rubber plantations in southern Laos, in: Singapore Journal of Tropical Geography, 40(1), p. 50-70.

6. BORRAS JR, S. M., LIU J., HU, Z., LI H., WANG C., XU Y., FRANCO J. C., YE J., 2018, Land control and crop booms inside China: implications for how we think about the global land rush, in: Globalizations, 15(1), p. 134-151.

7. DEVENDRA C., THOMAS D., 2002, Smallholder farming systems in Asia, in: Agricultural systems, 71(1-2), p. 17-25.

8. DIANA A., 2013, The experimental governing of mobility and trade on the China-Laos frontier: The Tai Lue case, in: Singapore Journal of Tropical Geography, 34(1), p. 25-39.

9. DIENER A. C., HAGEN J., 2012, Borders: A very short introduction, Oxford University Press.

10. DONNAN H., WILSOM T. M., 2001, Borders:

${ }^{3}$ It is available at: http://kpl.gov.la/En/Detail.aspx ?id= 23032. 
Frontiers of identity, nation and state, Berg, Oxford.

11. DONG J., XIAO X., SHELDON S., BIRADAR C., XIE G., 2012, Mapping tropical forests and rubber plantations in complex landscapes by integrating PALSAR and MODIS imagery, in: ISPRS Journal of Photogrammetry and Remote Sensing, 74, p. 2033.

12. EAKIN H., DEFRIES R., KERR S., LAMBIN E. F., LIU J., MARCOTULLIO P. J., MESSERLI P., REENBERG A., RUEDA X., SWAFFIELD S.R., WICKE B., ZIMMERER K., 2014, Significance of telecoupling for exploration of land-use change, in: Rethinking global land use in an urban era, eds Seto K. C., ReenbergA., MIT Press, p. 141-161.

13. EIA/TELEPAK, 2008, Borderlines: Vietnam 's booming furniture industry and timber smuggling in the Mekong Region, EIA and Telepak, London.

14. FOX J., 2009, Crossing borders, changing landscapes: land-use dynamics in the Golden Triangle, Honolulu.

15. FRIIS C., NIELSEN J. Ø., 2016, Small-scale land acquisitions, large-scale implications: Exploring the case of Chinese banana investments in Northern Laos, in: Land Use Policy, 57, p. 117-129.

16. FRIIS C. NIELSEN J. Ø. 2017a, Land-use change in a telecoupled world: the relevance and applicability of the telecoupling framework in the case of banana plantation expansion in Laos, in: Ecology and Society, 22(4), p. 30.

17. FRIIS C., NIELSEN J. Ø., 2017b, On the system. Boundary choices, implications, and solutions in telecoupling land use change research, in: Sustainability, 9(6), p. 974.

18. GAINSBOROUGH M., 2008, On the borders of state power: frontiers in the greater Mekong subregion, Routledge.

19. GALLAHER C., DAHLMAN C., GILMARTIN M., MOUNTZ A., SHIRLOW P., 2009, Key concepts in political geography, Sage.

20. GREGORY D., JOHNSTON R., PRATT G., WATTS M., WHATMORE S., 2011, The dictionary of human geography, John Wiley \& Sons.

21. HALL D., 2013, Land, Polity Press, Cambridge.

22. HUA X., KONO Y., ZHANG L., XU E., LUO R., 2019, How transnational labour migration affects upland land use practices in the receiving country: Findings from the China-Myanmar borderland, in: Land Use Policy, 84, p. 163-176.

23. HUA X., YAN J., LI H., HE W., LI X., 2016, Wildlife damage and cultivated land abandonment: Findings from the mountainous areas of Chongqing, China, in: Crop Protection, 84, p. 141-149.

24. KOJIMA T., BADENOCH N., 2013, From tea to temples and texts: transformation of the interfaces of upland-lowland interaction on the China-Myanmar Border, in: Southeast Asian Studies, 2(1), p. 95-131.

25. KOLOSSOV V., SCOTT J., 2013, Selected conceptual issues in border studies, in: Belgeo. Revue belge de géographie, (1), p. 1-19.

26. KONO Y., SATO T., WATANABE K., TOMITA S., ZHANG L., 2018, Reconsidering development Mechanisms of tropical agriculture: Focusing on micro-development in Mainland Southeast Asia, in: Environmental Resources Use and Challenges in Contemporary Southeast Asia, Springer, Singapore, p. 21-39.

27. KUBO K., 2016, Myanmar's cross-border trade with China: beyond informal trade, Institute of Developing Economies, Japan External Trade Organization (JETRO).

28. KUBO K., 2018, Myanmar's fresh fruit export to China via cross-border trade, in: Impact of China's Increasing Demand for Agro Produce on Agricultural Production in the Mekong Region, eds. Kubo K., Sakata S., Bangkok, Report No. 21.

29. LAHIRI-DUTT K., BROWN H., 2017, Governing the ungovernable? Reflections on informal gemstone mining in high-altitude borderlands of GilgitBaltistan, Pakistan, in: Local Environment, 22(11), p. 1428-1443.

30. LAMBIN E. F., GEIST H. J., 2008, Land-use and land-cover change: local processes and global impacts,: Springer Science \& Business Media.

31. LEISZ S. J., ROUNDS E., THI BICH YEN N., NGUYEN BANG T., DOUANFPHACHANH S., NINCHALEUNE B., 2016, Telecouplings in the east-west economic corridor within borders and across, in: Remote Sensing, 8(12), p. 1012.

32. LESSER C., MOISE-LEEMAN E., 2009, Informal cross-border trade and trade facilitation reform in Sub-Saharan Africa, OECD Publishing, Paris.

33. LIU J., 2017, Integration across a metacoupled world, in: Ecology and Society, 22(4), p. 29.

34. LIU J., 2018, An integrated framework for achieving Sustainable Development Goals around the world, in: Ecology, Economy and Society: the INSEE Journal, 1(2), p. 11-17.

35. LIU J., HULL V., BATISTELLA M., DEFRIES R., DIETZ T., FU F., HERTEL T. W., IZAURRALDE R. C., 2013, Framing sustainability in a telecoupled world, in: Ecology and Society, 18(2), p. 26.

36. LIU J., HULL V., MORAN E., NAGENDRA H., SWAFFIELD S. R., TURNER B., 2014, Applications of the telecoupling framework to landchange science, in: Rethinking global land use in an urban era, eds Seto K., Reenberg A., MIT Press, p. 119-139.

37. LIU M., QI Q., LIU J., ZOU X., LI J., 2006, Spatialtemporal changes of the land use/cover and its ecological effect analysis in trans boundary Yunnan Province, in: Yunnan Geographic Environment Research, 18(2), p. 1-5.

38. LU J. N., 2017, Tapping into rubber: China's opium replacement program and rubber production in Laos, in: The Journal of Peasant Studies, 44(4), p. 726747.

39. MEYFROIDT P., 2016, Approaches and terminology for causal analysis in land systems science, in: Journal of Land Use Science, 11(5), p. 501-522.

40. MEYFROIDT P., CHOWDHURY R. R., DE BREMOND A., ELLIS E., ERB K.-H., FILATOVA T., GARRETT R., GROVE J. et al., 2018, Middlerange theories of land system change, in: Global Environmental Change, 53, p. 52-67.

41. MINGHI J. V., 1991, From conflict to harmony in border landscapes, in: The geography of border landscapes, eds Rumley D., Minghi J.V., Routledge, London, New York, p. 15-30.

42. NEWMAN D., 2006, The lines that continue to separate us: borders in ourborderless' world, in: Progress in Human geography 30(2), p. 143-161.

43. PARKER B. J., 2006, Toward an understanding of borderland processes, in: American Antiquity 71(1), 
p. $77-100$.

44. PRESCOTT G. W., SUTHERLAND W. J., AGUIRRE D., BAIRD M., BOWMAN V., BRUNNER J., CONNETTE G. M., COSIER M. et al., 2017, Political transition and emergent forestconservation issues in Myanmar, in: Conservation Biology, 31(6), p. 1257-1270.

45. ROUSSEAU J. F., 2018, A failed market experiment and ignored livelihoods: Jatropha expansion in the Sino-Vietnamese borderlands, in: Routledge handbook of Asian borderlands, eds Horstmann A., Saxer M., Routledge, Abingon, New York, p. 202211.

46. ROUSSEAU J. F., STURGEON J., 2019, The disappearance of water buffalo from agrarian landscapes in Western China, in: Journal of Agrarian Change, 19(2), p. 319-336.

47. STEINBERG D. I., FAN H., 2012, Modern ChinaMyanmar relations: dilemmas of mutual dependence, Nias press.

48. STURGEON J. C., 2007, Border landscapes: the politics of Akha land use in China and Thailand, University of Washington Press, Seattle and London.

49. STURGEON J. C., 2010, Governing minorities and development in Xishuangbanna, China: Akha and Dai rubber farmers as entrepreneurs. In, Geoforum, 41(2), p. 318-328.

50. STURGEON J. C., 2013, Cross-border rubber cultivation between China and Laos: Regionalization by Akha and Tai rubber farmers, in: Singapore Journal of Tropical Geography, 34(1), p. 70-85.

51. TRINCSI K., TURNER S., 2014, Mapping mountain diversity: Ethnic minorities and land use land cover change in Vietnam's borderlands, in: Land Use Policy, 41, p. 484-497.

52. TURNER S., 2013, Under the state's gaze: Upland trading-scapes on the Sino-Vietnamese border. in: Singapore Journal of Tropical Geography, 34(1), p. 9-24.

53. VAN SCHENDEL W., 2005, The Bengal borderland: Beyond state and nation in South Asia, Anthem Press.

54. VERBURG P. H., HRB K. H., MERTZ O., ESPINDOLA G., 2013, Land system science: between global challenges and local realities. in: Current Opinion in Environmental Sustainbility, 5, p. 433-437.

55. WOODS K., 2012, The political ecology of rubber production in Myanmar: an overview, Global Witness, Yangon, Myanmar.

56. WOODS K., 2019, Rubber out of the ashes: locating Chinese agribusiness investments in 'armed sovereignties' in the Myanmar-China borderlands, in: Territory, Politics, Governance, 7(1), p. 79-95.

57. YAN J., YANG Z., LI Z., LI X., XIN L., SUN L., 2016, Drivers of cropland abandonment in mountainous areas: A household decision model on farming scale in Southwest China, in: Land Use Policy, 57, p. 459-469.

58. ZHANG L., KONO Y., KOBAYASHI S., 2014, The process of expansion in commercial banana cropping in tropical China: A case study at a Dai village, Mengla County, in: Agricultural Systems, 124 , p. $32-38$.

59. ZIMMERER K., LAMBIN E., VANEK S., 2018, Smallholder telecoupling and potential sustainability, in: Ecology and Society, 23(1), p. 30. 
